\title{
Anti-inflammatory prostaglandins for the prevention of preterm labour
}

\author{
Lynne Sykes, David A Maclntyre, Tiong Ghee Teoh ${ }^{1}$ and Phillip R Bennett
}

Parturition Research Group, Department of Surgery and Cancer, Institute of Reproduction and Developmental Biology, Imperial College London, London W12 ONN, UK and ${ }^{1}$ St Mary's Hospital, Imperial College Healthcare NHS Trust, London W1 2NY, UK

Correspondence should be addressed to L Sykes; Email: I.sykes@imperial.ac.uk

\begin{abstract}
Preterm birth occurs in 10-12\% of pregnancies and is the primary cause of neonatal mortality and morbidity. Tocolytic therapies have long been the focus for the prevention of preterm labour, yet they do not significantly improve neonatal outcome. A direct causal link exists between infection-induced inflammation and preterm labour. As inflammation and infection are independent risk factors for poor neonatal outcome, recent research focus has been shifted towards exploring the potential for anti-inflammatory strategies. Nuclear factor kappa B (NFKB) is a transcription factor that controls the expression of many labour-associated genes including PTGS2 (COX2), prostaglandins (PGs) and the oxytocin receptor $(O X T R)$ as well as key inflammatory genes. Targeting the inhibition of NF $\mathrm{B}$ is therefore an attractive therapeutic approach for both the prevention of preterm labour and for reducing neonatal exposure to inflammation. While PGs are considered to be pro-labour and pro-inflammatory, the cyclopentenone PG 15-deoxy- $\Delta^{\mathbf{1 2}_{14}} \mathrm{PGJ}_{2}\left(\mathbf{1 5 d}^{-P G J_{2}}\right)$ exhibits anti-inflammatory properties via the inhibition of NFKB in human amniocytes, myocytes and peripheral blood mononuclear cells in vitro. $15 \mathrm{~d}-\mathrm{PGJ}_{2}$ also delays inflammation-induced preterm labour in the mouse and significantly increases pup survival. This review examines the current understanding of inflammation in the context of labour and discusses how anti-inflammatory PGs may hold promise for the prevention of preterm labour and improved neonatal outcome.
\end{abstract}

Reproduction (2014) 148 R29-R40

\section{Introduction}

The timing of human birth is a carefully regulated event that normally occurs following 37-42 weeks gestation. Being born outside this timeframe has immense consequences for both the mother and neonate. In 2010, an estimated 14.9 million babies worldwide were born preterm (before 37 weeks gestation), equating to $11.1 \%$ of all live births (Blencowe et al. 2012). Prematurity remains the leading cause of neonatal death, and the second most common cause of death after pneumonia in children under 5 years of age (Liu et al. 2012). In the vast majority of countries, including the UK, the rate of preterm birth is on the increase (Sykes et al. 2011, Blencowe et al. 2012). Although survival rates have improved over the last few decades due to advancements in neonatal care, morbidity rates remain unaltered (Fanaroff et al. 2003). This has led to a growing sense of urgency from governments and research bodies to prioritise research directed towards understanding the mechanisms underpinning preterm birth as well as the development of new treatment strategies for its prevention (Howson et al. 2012).
While a proportion of preterm births is medically indicated or 'caregiver initiated' (Goldenberg et al. 2012), the majority results from spontaneous labour and/or premature preterm rupture of membranes (Gravett et al. 2010). In absolute numbers, the increasing rate of preterm birth appears to be derived equally from increasing numbers of both spontaneous and caregiverinitiated preterm births (Norman et al. 2009). The main challenge in developing preventative strategies to reduce the incidence of preterm birth lies in the heterogeneous nature of the aetiologies of spontaneous preterm birth, often referred to as a syndrome, inferring that no single strategy could cover all causes (Villar et al. 2012). In order to overcome this challenge, it is essential to develop a preventative strategy that targets the activation of common biological pathways leading to cervical remodelling, foetal membrane rupture and uterine contractility.

Normal term labour is often described as a proinflammatory state. There is mounting evidence that the presence of inflammation in the absence of infection is sufficient to cause preterm labour (Shim et al. 2004, Christiaens et al. 2008). Moreover, inflammation is a risk 
factor for adverse neonatal outcomes independent of gestational age of delivery. Taking this into account, anti-inflammatory therapies are attractive not only for the prevention of preterm labour but also as a means to confront associated adverse neonatal outcomes. This review summarises the key pathways involved in term and preterm labours, with particular emphasis on the role of inflammation, and provides evidence supporting the future potential use of anti-inflammatory prostaglandins (PGs) for the treatment of preterm labour and improved neonatal outcome.

\section{The role of PGs in labour and inflammation \\ PG synthesis}

PGs play a central role in the processes involved in term and preterm labour, contributing to uterine contractility, membrane rupture and cervical ripening. PGs are unsaturated fatty acids, containing 20 carbon atoms derived from membrane phospholipids under the action of phospholipases, primarily phospholipase $A_{2}$, that release arachidonic acid into the cytoplasm (Simmons et al. 2004). Arachidonic acid is then converted to $\mathrm{PGH}_{2}$ by the cyclo-oxygenase enzymes COX1 and COX2 (also known as PG endoperoxide $\mathrm{H}$ synthases 1 and 2 respectively). $\mathrm{PGH}_{2}$ is the substrate for the specific synthase enzymes that produce the four principal PGs: $\mathrm{PGE}_{2}, \mathrm{PGF}_{2 \alpha}, \mathrm{PGD}_{2}$ and prostacyclin $\left(\mathrm{PGI}_{2}\right)$. Subsequent conversion of $\mathrm{PGE}_{2}$ and $\mathrm{PGD}_{2}$ by non-enzymatic dehydration reactions leads to the production of the cyclopentenone PGs: $\mathrm{PGA}_{2}$, 15-deoxy- $\Delta^{12,14} \mathrm{PGA}_{2}$, $\mathrm{PGJ}_{2}$ and 15 -deoxy- $\left.\left.\Delta^{12,14} \mathrm{PG}\right)_{2}(15 \mathrm{~d}-\mathrm{PG})_{2}\right)$ as shown in Fig. 1.

PG synthesis is regulated at several steps to ensure quiescence for the maintenance of pregnancy, and increased production in preparation for labour. Expression of $s P L A_{2} G 1 B\left(P L A_{2}\right)-I I A$ is increased in human myometrium in preterm and term labour compared with non-labouring subjects (Slater et al. 2004).
Although no labour-associated changes in $\mathrm{PLA}_{2}$ are seen in amnion with the onset of labour (Bennett et al. 1994), an increase in maternal plasma immunoreactive $\mathrm{PLA}_{2}$ has been shown in term and preterm labour (Rice et al. 1992). Production of PGs is also regulated by the activity of the cyclo-oxygenase enzymes. Although PTGS1 (COX1) is constitutively expressed in most cell types, PTGS2 (COX2) is an inducible enzyme which is particularly responsive to inflammatory stimuli (Morita 2002). Expression of PTGS2 but not PTGS1 is increased at term in amnion, choriodecidua and myometrium, with a further increase after labour in foetal membranes (Slater et al. 1999a,b). PG production can be further modulated by PG synthases. For example, the onset of human labour is accompanied by an increase in microsomal PGES1 and PGES2 in the myometrium (Astle et al. 2007) but not cytosolic PGES. During pregnancy, PG synthesis is negatively regulated by the presence of prostaglandin dehydrogenase. 15-Hydroxyprostaglandin dehydrogenase is the primary enzyme metabolising PGs, and during pregnancy it is found at high levels in the chorion, decidua, placenta, myometrium and cervix (Sangha et al. 1994, Ramirez et al. 1995, Giannoulias et al. 2002), with levels decreasing with the onset of term and preterm labour (Olson \& Ammann 2007).

\section{The role of PGs in labour}

Successful birth involves uterine activation, cervical ripening and foetal membrane remodelling. PGs play an important role in the coordinated activation of these processes. The principal site of production of PGs in labour is the amnion where there is increased production of $\mathrm{PGE}_{2}$ and $\mathrm{PGF}_{2 \alpha}$ with the onset of labour (Olson et al. 1983). $\mathrm{PGE}_{2}$ and $\mathrm{PGF}_{2 \alpha}$ are potent inducers of spontaneous uterine contractility (Crankshaw \& Dyal 1994). Upon stimulation of the PTGER1 (EP 1 ) and PTGER3 $\left(\mathrm{EP}_{3}\right)$ receptors, PTFS1 $\left(\mathrm{PGE}_{2}\right)$ leads to calcium

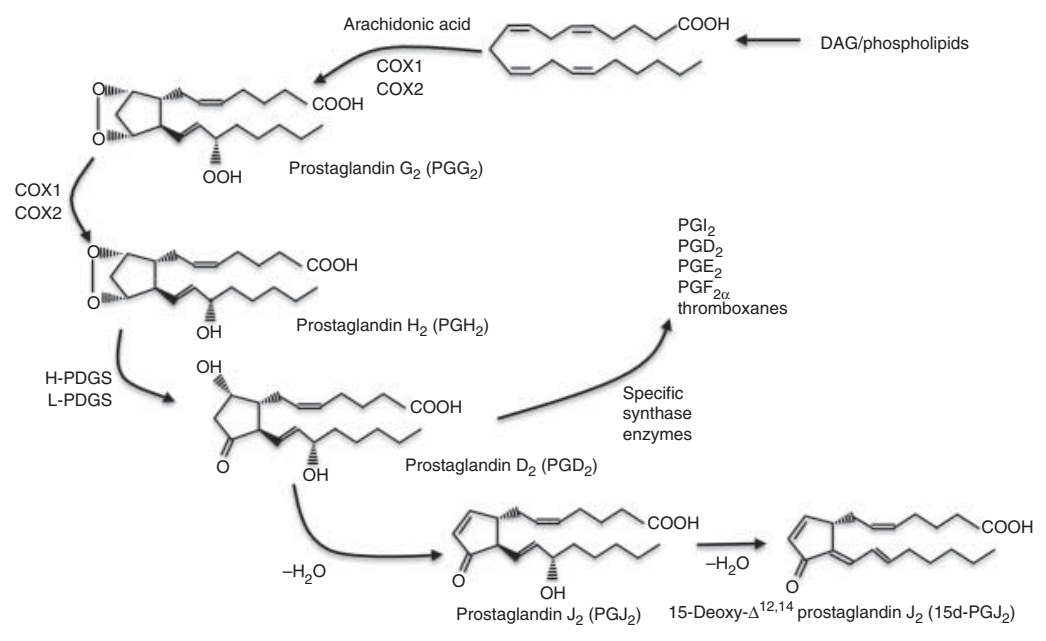

Figure 1 Arachidonic acid liberation and prostaglandin (PG) biosynthesis. Arachidonic acid is derived from membrane diacylglycerol (DAG) or phospholipids via phospholipase enzymes $\left(\mathrm{PLA}_{2}\right)$ before it is converted to $\mathrm{PGG}_{2}$ and then $\mathrm{PGH}_{2}$ by cyclooxygenase (COX2). $\mathrm{PGH}_{2}$ is then converted to $\mathrm{PGD}_{2}$ through the action of specific $\mathrm{PGD}_{2}$ synthases (H-PGDS and L-PDGS) or alternatively may be converted to other PGs including $\mathrm{PGI}_{2}, \mathrm{PGD}_{2}, \mathrm{PGE}_{2}$, and $\mathrm{PGF}_{2 \alpha}$ and thromboxanes. Via chemical dehydration, $\mathrm{PGD}_{2}$ forms cyclopentenone $P G \mathrm{PGJ}_{2}$ and finally $15 \mathrm{~d}-\mathrm{PG} \mathrm{J}_{2}$. 
release via inositol triphosphate and adenylate cyclase and CAMP inhibition respectively (Blanks et al. 2007). However, recent data have suggested that spontaneous and $\mathrm{PGE}_{2}$-induced myometrial contractility is via the PTGER3 rather than the PTGER1 receptor (Arulkumaran et al. 2012). PGF $_{2 \alpha}$ also stimulates myometrial contractility through the FP receptor (PTGFR) likely by increasing intracellular calcium mobilisation (Parkington et al. 1999). $\mathrm{PGE}_{2}$ aids cervical ripening by decreasing the concentration of collagen (Ekman et al. 1986), and increasing the synthesis of proteoglycans (Norman et al. 1993). Evidence is also emerging of a direct role of $\mathrm{PGE}_{2}$ on foetal membrane rupture, via the remodelling of the extracellular matrix through increased expression of matrix metalloproteinases (MMPs), for example MMP9 (McLaren et al. 2000). Similarly, PGF $_{2 \alpha}$ increases the production of MMP9 in decidua (Ulug et al. 2001).

\section{The role of PGs in inflammation}

PGs are typically thought of as having predominantly pro-inflammatory effects. Their biosynthesis is increased in inflamed tissue and they contribute to the development of the cardinal signs of acute inflammation: dolor (pain), calor (heat), rubor (redness) and tumor (swelling). Pain sensation occurs due to $\mathrm{PGE}_{2}$-mediated action on peripheral sensory neurones and centrally within the spinal cord and brain (Funk 2001). PGE 2 is also responsible for redness and swelling caused by increased blood flow in inflamed tissue through the augmentation of arterial dilatation and increased microvascular permeability (Funk 2001). Moreover, PGs can induce the expression and release of various chemokines, leading to infiltration of the inflammatory cell at the site of inflammation (Aoki \& Narumiya 2012).
The release of cytokines by these cells can further drive PG synthesis by increasing PTGS2 expression (Aoki \& Narumiya 2012). Consistent with this role, PGs contribute to the physiological inflammatory response seen at the time of labour. For example, $\mathrm{PGE}_{2}$ enhances migration of leukocytes towards the cervix, which in turn leads to an increased production of interleukin 8 (IL8; Hertelendy \& Zakar 2004), and PGF $_{2 \alpha}$ indirectly leads to the activation of IL1 $\beta$ in the decidua and consequently the increased production of MMP9 (Schonbeck et al. 1998, Christiaens et al. 2008). PGF $2 \alpha$ has also been shown to increase CON43 and PTGS2 expression in myocytes, the effect of which is enhanced by IL1 $\beta$ (Xu et al. 2013).

\section{The role of nuclear factor kappa $B$ in labour and inflammation}

It is increasingly recognised that labour onset represents the culmination of numerous converging signalling pathways that are both maternal and neonatal in origin. These pathways lead to a common node that involves the activation of inflammation in gestational tissues. A key regulator of these pathways is the transcription factor nuclear factor kappa B (NFкB; Lindstrom \& Bennett 2005a, Lappas \& Rice 2009). NFאB is a protein complex consisting of five family members: NFKB1 (p105/p50), NFкB2 (p100/52), Rel A (p65), Rel B and c-Rel (Lindstrom \& Bennett 2005a). NFKB subunits are typically localised in the cytoplasm as inactive homo or hetero dimers, where they are complexed with the inhibitor protein, $\mathrm{I} \kappa \mathrm{B}$ as shown in Fig. 2. Phosphorylation of $I \kappa B$ by $I \kappa B$ kinase (IKK) at specific serine residues (Zandi et al. 1997) results in the attachment of ubiquitin residues (Chen et al. 1995) and subsequent cleavage by

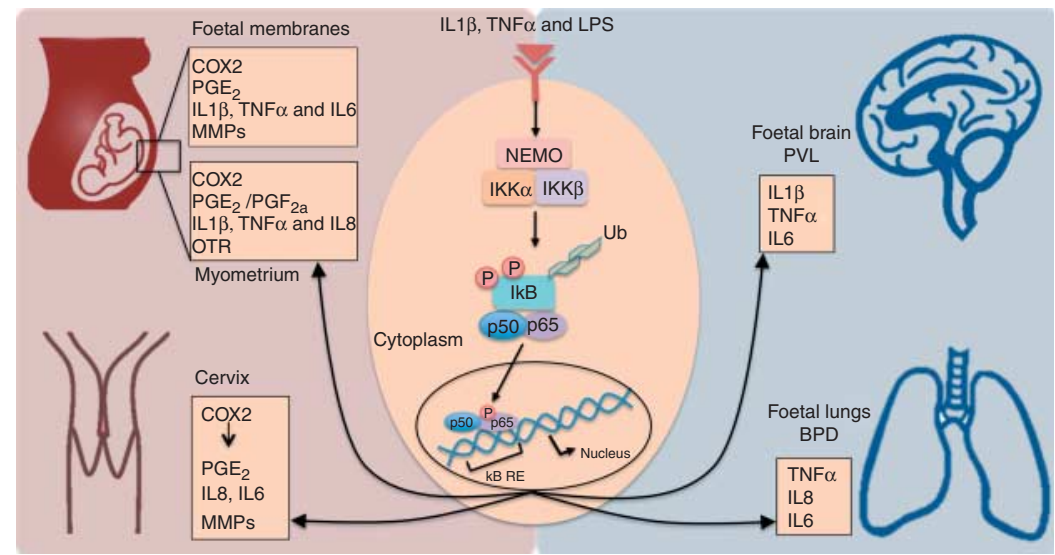

Figure 2 Downstream effects of NFKB activation in gestational tissues and implications for the foetus. The transcription factor $\mathrm{NF} \kappa \mathrm{B}$ is key to control the expression of labour-associated genes and inflammatory response genes. IKK $\beta$ phosphorylates I $\mathrm{B}$ in response to a pro-inflammatory stimulus. This results in the attachment of ubiquitin residues which are then cleaved by the 26 s proteosome, allowing the free $\mathrm{NF} \kappa \mathrm{B}$ subunits to translocate into the nucleus to bind to NFKB response elements. The resulting effect is the release of pro-inflammatory cytokines and the production of contractileassociated proteins in foetal membranes, myometrium and cervix, which ultimately lead to membrane rupture, uterine contractility and cervical dilation. As a result of an exaggerated inflammatory response, the blood-brain barrier becomes more permeable making the neonate more susceptible to brain injury, and the lung is also targeted resulting in BPD. PVL, periventricular leukomalacia; BPD, bronchopulmonary dysplasia. 
the $26 \mathrm{~S}$ proteosome (Karin \& Ben-Neriah 2000). Liberated NFKB subunits undergo activation by phosphorylation, permitting their translocation into the nucleus where they bind to the DNA response elements of target genes leading to their transcriptional activation.

Consistent with a role in the activation of inflammation before the onset of human labour, increased NFKB activity can be detected in the amnion from preterm labour patients (Lim et al. 2012). Similarly, nuclear translocation of p65 is evident in the upper and lower segments of the uterus at term, consistent with NFKB playing a central role in the events preceding labour (Khanjani et al. 2011). As further evidence supporting the importance of $\mathrm{NF \kappa B}$ in the processes leading up to labour and delivery, several NFKB inhibitors SN-50, sulphasalazine and $15 \mathrm{~d}-\mathrm{PG} \mathrm{J}_{2}$ have been shown to delay preterm labour in the mouse (Condon et al. 2004, Pirianov et al. 2009, Nath et al. 2010).

\section{$N F_{K} B$ regulation of labour-associated and inflammatory response genes}

$\mathrm{NF} \kappa \mathrm{B}$ plays a pivotal role in the transcriptional regulation of numerous genes associated with the activation of labour. Figure 2 summarises the downstream effects of $\mathrm{NF \kappa B}$ activation in gestational tissues and their resulting potential implications for the foetus. Key genes involved in the synthesis and expression of PGs including $s P L A_{2} G 1 B-I I A, C P L A_{2}$ (Lappas \& Rice 2007), PTGS2 (Allport et al. 2001) and PGF $_{2 \alpha}$ receptor expression (Zaragoza et al. 2006, Liang et al. 2008) have been shown to be NFKB regulated. Similarly, the oxytocin receptor (OXTR (OTR)) gene responsible for propagating uterine oxytocin stimulation contains several NFKB response elements in its promoter region, and thus activation of $\mathrm{NF \kappa B}$ likely contributes to the observed increase in OXTR expression at term (Terzidou et al. 2006). NFкB is also involved in the transcriptional regulation of MMPs, including MMP9, which are required for remodelling of the extracellular matrix (Choi et al. 2007), leading to both cervical ripening and foetal membrane rupture.

$N F \kappa B$ also plays a central role in modulating the expression of key inflammatory genes associated with parturition. NFKB activity is highly inducible by proinflammatory stimuli such as lipopolysaccharide (LPS), tumour necrosis factor alpha (TNF $\alpha$ ) and IL1 $\beta$ via the canonical pathway. Considering many cytokines that contain NFKB recognition elements within their promoter regions (e.g. TNF $\alpha$, IL1 $\beta$, CXCL8 (IL8) and IL6 (Lindstrom \& Bennett 2005a)), NFKB activation by inflammatory stimuli can lead to the formation of a feed forward loop and activation of persistent inflammatory pathway. Although immune cells are recognised as major producers of pro-inflammatory cytokines, myocytes, amniocytes and placental cells also contribute to a pro-inflammatory environment during term and preterm labour (Keelan et al. 2003). Overexpression of NFאB in myocytes leads to the upregulation of a cassette of genes that are principally involved in immunity and inflammation (Khanjani et al. 2011). Furthermore, the transcription of chemokines, such CXCL8, by myocytes, amniocytes and cervical cells is regulated at least in part by NFKB (Elliott et al. 2001, Soloff et al. 2004).

\section{The role of infection and inflammation in preterm labour}

Spontaneous labour at term is characterised by a molecular inflammatory signature in the foetal membranes, myometrium and cervix (Blank et al. 2008). Mathematical modelling of the three main pathways thought to be involved in labour onset; inflammatory stimulation, functional progesterone withdrawal or OXTR activation, strongly point to inflammation as being the primary driver for the activation of the myometrium for labour to ensue (Bisits et al. 2005). It therefore follows that premature activation of inflammatory pathways could lead to the untimely activation of myometrial contractions and labour. Consistent with this, infection and/or inflammation are the only well-defined pathological processes at the molecular level in which a firm causal link with preterm labour has been established. Although between 25 and $40 \%$ of preterm births are thought to be attributed to intrauterine microbial infection (Goldenberg et al. 2000), inflammation in the absence of infection can be sufficient to cause preterm labour (Shim et al. 2004, Christiaens et al. 2008).

\section{Gestational tissue-level inflammation}

In response to an intrauterine infection, the maternal system mounts an immune response, whereby infiltrating leukocytes and decidual cells secrete proinflammatory cytokines including IL $1 \alpha$ (IL1), IL6, CXCL8 and TNF $\alpha$ (Casey \& MacDonald 1988, Romero \& Mazor 1988, Hunt 1989). These cytokines are elevated in the amniotic fluid and foetal membranes in preterm labour patients (Keelan et al. 2003), where they likely induce PG production in the foetal membranes and deciduas, leading to the premature initiation of foetal membrane remodelling manifested in the form of preterm premature ruptures of membranes (PPROM) (Romero et al. 1989, Mitchell et al. 1990). Supporting evidence for this comes from in vitro experimentation which shows that exposure of amnio-chorion to TNF $\alpha$ increases the activity of MMPs, drives IL1 $\beta$ and TNF $\alpha$ production and induces apoptosis - all characteristic processes of foetal membrane rupture (Menon \& Fortunato 2004).

An elevated immune signature in the cervix is also associated with preterm labour. Both IL6 and IL8 levels are significantly higher in cervical secretions of women destined to deliver preterm (Becher et al. 2009). IL8 may 
play a role in cervical ripening by chemo-attracting leukocytes such as neutrophils, which produce MMPs and $\mathrm{PGE}_{2}$ (Ogawa et al. 1998, Wright et al. 2010). The cervix plays both a mechanical and biochemical protective role during pregnancy in the prevention of ascending infection as demonstrated by the higher incidence of microbial invasion of the amniotic fluid in women with a shorter cervix (Gomez et al. 2005a, Hassan et al. 2006).

While often considered to be the 'engine' of parturition, the myometrium also responds to and propagates inflammatory signalling during parturition. During preterm labour, the myometrium experiences marked leukocyte invasion (Thomson et al. 1999), along with increased levels of pro-inflammatory cytokines such as CXCL8 and IL1 $\beta$ (Tattersall et al. 2008). IL1 $\beta$ stimulates the production of PGs (Pollard \& Mitchell 1996a,b, Todd et al. 1996) by stimulating the release of arachidonic acid (Molnar et al. 1993) and increasing PTGS2 expression (Belt et al. 1999). IL1 $\beta$ also increases oxytocin production, which also leads to increased uterine contractility (Friebe-Hoffmann et al. 2001).

\section{Systemic inflammation}

NFKB activity and T helper 1 (Th1) cytokine production in peripheral blood mononuclear cells (PBMCs) are suppressed in pregnancy compared with non-pregnant controls (McCracken et al. 2003, Sykes et al. 2012a). The reduction in pro-inflammatory cytokine production in PBMCs is likely to be as a result of the downregulation of the $\mathrm{NF \kappa B} / \mathrm{l} \kappa \mathrm{B}$ signalling pathway (McCracken et al. 2004, 2007). Detecting signs of an overt systemic inflammatory reaction is rare in women presenting in threatened preterm labour in the clinical setting with conventional tests. However, several groups have been able to demonstrate an association between the expression of pro-inflammatory cytokines in serum or PBMCs and women at risk and/or in preterm labour (Raghupathy et al. 2001, Makhseed et al. 2003, Curry et al. 2007).

\section{Inflammation and adverse neonatal outcome}

The presence of infection and/or inflammation is now considered an independent risk factor for the adverse neonatal outcome. For example, amniotic fluid and cord blood pro-inflammatory cytokines IL1 $\beta$, IL6 and TNF $\alpha$ are associated with radiological evidence of cerebral damage (Yoon et al. 1997, Duggan et al. 2001) and chronic lung disease (Yoon et al. 1999). It is likely that the same transcription factors activated in preterm labour also play a role in inflammation-induced brain damage (Yuan et al. 2010). Preventative therapies should therefore focus on targeting these transcription factors to prevent both preterm labour and the associated neonatal sequelae.

\section{Current strategies for the prevention of preterm labour}

Regardless of great research effort, there has been little advancement in the therapeutic approaches aimed to tackle preterm labour. Clinical management strategies can be roughly divided into acute management and prophylactic therapies.

Historically, tocolytics have been used in an attempt to delay preterm labour by inhibiting uterine contractility. These include oxytocin antagonists (atosiban), calcium channel blockers (nifedipine), $\beta$-mimetics (e.g. terbutaline) and non-steroidal anti-inflammatory agents (e.g. indomethacin). A short course of tocolysis is given to women in threatened preterm labour to allow time for the corticosteroids administered to stimulate foetal maturation; however, no long-term neonatal benefits from tocolysis have been demonstrated. This may partly be due to the inclusion of mostly women who are not destined to labour despite presenting in threatened preterm labour. In the case of women who genuinely require tocolysis, the pathways leading to labour are likely, in many cases, to be well established to be overcome by transient inhibition of the contractions. Another limitation of tocolysis is the targeting of only one late aspect of preterm labour - uterine contractions, while having no effect on the causal aspects or on the aetiologies of the adverse effect of the neonate.

Prophylactic treatment of preterm labour is therefore an attractive treatment strategy as it theoretically offer the means to prevent the activation of myometrial contractions but also distally inhibit associated inflammation and other causal pathways of neonatal injury. One such approach is cervical cerclage. A meta-analysis of 208 women with a short cervix reported on a statistically significant reduction in rate of preterm delivery $<35$ weeks with cerclage placement (relative risk 0.61; 95\% Cl 0.4-0.92; Berghella et al. 2010). There is also evidence that cervical cerclage in women at high risk of preterm labour results in a statistically significant reduction of a composite of perinatal mortality and morbidity (Berghella et al. 2011).

Similarly, several large trials have now been conducted to examine the effect of progesterone prophylaxis in women at high risk of preterm labour. While not unambiguous, there is a general consensus that progesterone treatment leads to a reduction in rates of preterm birth (da Fonseca et al. 2003, Meis et al. 2003, Fonseca et al. 2007, Hassan et al. 2011). However, the primary outcome of the majority of these studies was gestation length rather than neonatal outcome and thus limited evidence is available for short and long-term benefits to the neonate/infant with progesterone supplementation.

\section{Anti-inflammatory effects of PGs}

Although the pro-inflammatory effects of PGs are well documented, there is also evidence that PGs may also act to resolve inflammation. 


\section{Prostaglandin $E_{2}$}

$\mathrm{PGE}_{2}$ can act as an immunosuppressant by creating a Th2 bias over Th1 cytokine production. This occurs by both enhancing Th2 cytokine production while reducing the production of IFN $\gamma$ and IL2 from Th1 cells, and also by repressing the differentiation of Th1 cells (Hilkens et al. 1996, Aoki \& Narumiya 2012). PGE 2 can significantly reduce IL $1 \beta$-mediated IL8 production in cultured human myocytes, which is likely to be via the $\mathrm{EP}_{2} / \mathrm{EP}_{4}$ receptors (Slater et al. 2006). Data also support a neuroprotective role in models of inflammation by limiting cytokine release and further PG synthesis in a negative feedback mechanism through the inhibition of mPGES1 (Ricciotti \& FitzGerald 2011). PGE 2 has been shown to inhibit the translocation of the p50/p65 subunit, thus inhibiting NFKB activity in stimulated rheumatoid synovial fibroblasts (Gomez et al. 2005b). As NFKB activation leads to COX2 synthesis and ultimately PG synthesis, it seems plausible that this inhibition by $\mathrm{PGE}_{2}$ serves an important role of negative feedback in regulating its own synthesis.

\section{Prostaglandin $\mathrm{D}_{2}$}

The placenta produces considerable amounts of $\mathrm{PGD}_{2}$, which has been shown in vitro to have anti-inflammatory effects in villous trophoblast cells through the inhibition of IL6 production (Helliwell et al. 2006). $\mathrm{PGD}_{2}$ production by the placenta is thought to be responsible for the anti-inflammatory Th2 cytokine predominance at the maternal foetal interface via the chemoattraction of $\mathrm{CRTH} 2{ }^{+}$Th2 cell interface (Saito et al. 2002).

\section{Cyclopentenone PGs}

PGs of the A and J series contain a cyclopentenone ring which is characterised by the presence of an $\alpha, \beta$ unsaturated carbonyl group. The electrophilic nature of the carbonyl group allows it to form Michael adducts with nucleophilic amino acid residues of proteins such as cysteine, histidine and lysine (Gharbi et al. 2007). Unlike most PGs that mainly act via G protein-coupled receptors, cyclopentenone PGs are capable of targeting intracellular proteins such as signalling molecules and transcription factors.

\section{$P G A_{1}$ and $P G A_{2}$}

$\mathrm{PGA}_{1}$ and $\mathrm{PGA}_{2}$ are formed from $\mathrm{PGE}_{1}$ and $\mathrm{PGE}_{2}$, respectively, through a non-enzymatic dehydration reaction. The resulting $\alpha, \beta$-unsaturated carbonyl group located within the cyclopentenone ring is thought to largely determine bioactivity capacity to inhibit different components of the NFKB signalling pathway in both the cytosol and the nucleus by forming covalent adducts with nucleophiles (Diez-Dacal \& Perez-Sala 2012). For example, $\mathrm{PGA}_{1}$ has been shown to inhibit $\mathrm{NF \kappa B}$ dependent PTGS2 expression in 3T3 fibroblasts (Mandal et al. 2005), whereas $\mathrm{PGA}_{2}$ has been shown to possess potent anti-inflammatory properties in murine microglia and astrocytes through inhibition of pro-inflammatory cytokine and chemokine production (Storer et al. 2005).

\section{Prostaglandin $J_{2}$}

The anti-inflammatory effects of $\mathrm{PGD}_{2}$ are further enhanced via the non-enzymatic generation of the $\mathrm{PGJ}_{2}$ family. The $J_{2}$ series of PGs were first discovered in the 1980s (Santoro et al. 1987) when Fukushima et al. showed that $\mathrm{PGD}_{2}$ undergoes spontaneous dehydration to $P G J_{2}$ in aqueous solutions, and when in the presence of albumin, $\mathrm{PGJ}_{2}$ isomerises to form $\Delta^{12}-\mathrm{J}_{2}$. This can be further metabolised by dehydration to form the most studied of the $P G J_{2}$ metabolites, $15 \mathrm{~d}-\mathrm{PG} \mathrm{J}_{2}$. As well as the reactive carbon in the $\alpha, \beta$-unsaturated carbonyl group, $\Delta^{12}-J_{2}$ and $15 d-P G J_{2}$, features a second reactive electrophilic carbon on one of their side chains (Straus \& Glass 2001).

\section{5-Deoxy- $\Delta^{12,14} P G J_{2}$}

$15 \mathrm{~d}-\mathrm{PG} \mathrm{J}_{2}$ has cell surface receptors as targets, DP1 and PTGSR2 (CRTH2); however its anti-inflammatory properties can be attributed mainly to its intracellular targets: $\mathrm{NF \kappa B}, \mathrm{AP1}$ and PPAR $\gamma$ nuclear receptor. It is still not known how $15 \mathrm{~d}-\mathrm{PG} \mathrm{J}_{2}$ enters the cell or nucleus to act upon these receptors; however, it is likely that an active transport mechanism facilities entry similar to the entry of other cyclopentenone PGs (Narumiya \& Fukushima 1987). In addition, the action of endogenous $15 d-\mathrm{PGJ}_{2}$ may be through its production within the cell from locally produced $\mathrm{PGD}_{2}$.

Endogenous $15 \mathrm{~d}-\mathrm{PG} \mathrm{J}_{2}$ can be detected in inflammatory fluid, with levels increasing in the resolution phase, supporting its anti-inflammatory role (Straus \& Glass 2001). In vitro studies show that $15 \mathrm{~d}-\mathrm{PG} \mathrm{J}_{2}$ can reduce neutrophil migration (Napimoga et al. 2008) and inhibit the secretion of IL6, IL1 $\beta$, IL12 and TNF $\alpha$ from macrophages (Scher \& Pillinger 2009). Repression inflammatory response gene transcription in macrophages has been shown to be via inhibition of $N F \kappa B$ and AP1 activation in a PPAR $\gamma$ dependent mechanism (Ricote et al. 1998). However, evidence suggests that $15 \mathrm{~d}-\mathrm{PG} \mathrm{J}_{2}$ can also act in a receptor-independent manner to inhibit NFKB. The highly reactive ring of $15 \mathrm{~d}-\mathrm{PGJ}_{2}$ can form a covalent interaction with multiple components of the NFKB signalling pathway (IkB kinase complex B, p50 and p65 subunits) via the Michael reaction, resulting in impaired nuclear entry and DNA-binding activity (Cernuda-Morollon et al. 2001) as shown in Fig. 3. Similarly, $15 \mathrm{~d}-\mathrm{PGJ}_{2}$ can act through a receptor-independent mechanism by directly binding to c-jun, a component of the AP1 signalling pathway leading to inhibition of DNA-binding activity (Perez-Sala et al. 2003). Since AP1 contributes to the induction of 


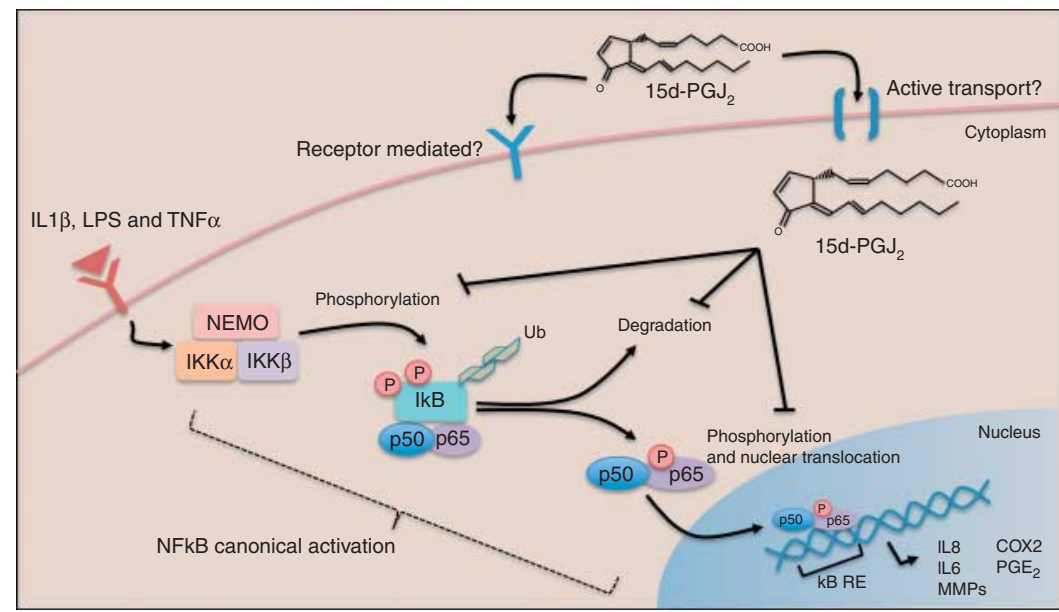

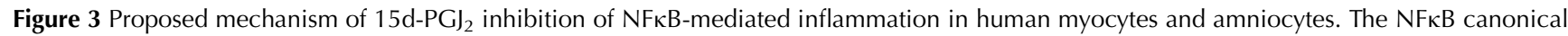
pathway is activated when inflammatory stimuli including interleukin 1 beta (IL1 $\beta$ ) or lipopolysaccharide (LPS) are recognised at the cell surface by

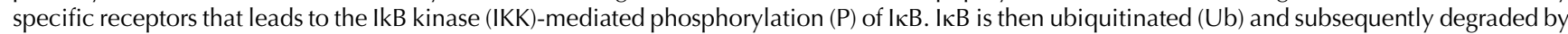
the proteasome-releasing p50/p65 dimers. p65 is then phosphorylated enabling p50/p65 dimer translocation to the nucleus where it binds to NFKB response elements $(\kappa B R E)$ in the promoter of inflammatory target genes. $15 \mathrm{~d}-\mathrm{PG} \mathrm{J}_{2}$ can impede this pathway by preventing IL $1 \beta$-stimulated I $\kappa \mathrm{B} \alpha$ degradation, inhibiting IKK phosphorylation and by directly interaction with the p65 subunit, can prevent nuclear translocation of the p50/p65 dimer. It remains unclear if the mode of cellular entry of $15 \mathrm{~d}-\mathrm{PG} \mathrm{J}_{2}$ into human amniocytes and myocytes is via active transport or a yet to be identified receptor.

expression of inflammatory response genes such as PTGS2 and CXCL8, it is plausible that $15 \mathrm{~d}-\mathrm{PG} \mathrm{J}_{2}$ and other cyclopentenone PGs also elicit their antiinflammatory effects via the AP1 signalling pathway, yet this remains to be investigated.

\section{Application of anti-inflammatory PGs for the prevention of preterm labour}

To date, the most researched anti-inflammatory PG in the context of the prevention of preterm labour is $15 d-P G J_{2}$, yet these studies are limited to in vitro experimentation in human cells and explants or in vivo animal studies. In either case, the collective consensus is that $15 \mathrm{~d}-\mathrm{PGJ} \mathrm{J}_{2}$ attenuates pathways associated with labour onset through the inhibition of the expression of labourassociated and inflammatory response genes. Therefore this section will focus upon how $15 \mathrm{~d}-\mathrm{PG}_{2}$ may be potentially used as a therapeutic agent for the treatment of preterm labour and birth.

\section{Human studies}

Our group have previously shown that $15 \mathrm{~d}-\mathrm{PG} \mathrm{J}_{2}$ inhibits NFKB activity in IL1 $\beta$-stimulated cultured human amniocytes and myocytes at concentrations between 16 and $32 \mu \mathrm{m}$ (Lindstrom \& Bennett 2005b). The cyPG acts at multiple steps in the NFKB signalling pathway, preventing IL1 $\beta$-stimulated I $\mathrm{K} \boldsymbol{\alpha} \alpha$ degradation, IKK phosphorylation and by directly targeting the p65 subunit. The inhibition of NFKB activity is dependent on the electrophilic carbon, and although $\mathrm{PGA}_{1}$ was also able to reduce nuclear translocation of p65, this effect was seen at concentrations sixfold as that of $15 \mathrm{~d}-\mathrm{PG} \mathrm{J}_{2}$, which is likely to be attributable to the presence of one, and not two, electrophilic carbons. This study also demonstrated that NFKB inhibition in amniocytes and myocytes is independent of the PPAR nuclear receptors. We have also excluded the role of the $G$ protein-coupled receptor, PTGSR2, in 15d-PG) ${ }_{2}$-mediated NFKB inhibition in amniocytes and myocytes (Sykes et al. 2012b). Both cyclopentenone PGs, $15 \mathrm{~d}-\mathrm{PGJ}_{2}$ and $\mathrm{PGA}_{1}$, inhibit IL1 $\beta$-nduced PTGS2 expression in amniocytes and myocytes, again, independently of the PPAR nuclear receptors because agonists of PPAR $\gamma$ and PPAR $\alpha$ failed to replicate this effect (Lindstrom \& Bennett 2005b). Consistent with these results, $30 \mu \mathrm{m}$ of $15 \mathrm{~d}-\mathrm{PGJ}_{2}$ has been shown to significantly reduce TNF $\alpha$-stimulated PTGS2 and PGE 2 synthesis in amniocytes in a PPAR $\gamma$ independent mechanism (Ackerman et al. 2005).

At $10 \mu \mathrm{m} 15 \mathrm{~d}-\mathrm{PGJ}_{2}$ significantly reduces the production of the pro-inflammatory cytokines, IL6 and CXCL8, from amnion-derived WISH cells in a PPAR $\gamma$ independent manner (Berry et al. 2005). Inhibition of LPS-stimulated IL6, IL8 and TNF $\alpha$ in amnion, choriodecidual and placental explants can also be demonstrated albeit at higher concentrations $(30 \mu \mathrm{m}$; Lappas et al. 2002). Similar anti-inflammatory effects can be seen in PBMCs isolated from women at different stages of pregnancy and from those in labour. In these cells, $15 \mathrm{~d}-\mathrm{PG} \mathrm{J}_{2}$ significantly reduces the PMA/lonomycinstimulated phosphorylation of p65 and the downstream production of IFN $\gamma$ and TNF $\alpha$ (Sykes et al. 2012c). 


\section{Animal studies}

In exploring the plausibility of using $15 \mathrm{~d}-\mathrm{PG}_{2}$ as a therapeutic treatment for preterm birth in an in vivo system, we reported that $4 \mu \mathrm{g}$ of intrauterine $15 \mathrm{~d}-\mathrm{PGJ}_{2}$ delays LPS-induced preterm labour in the mouse (Pirianov et al. 2009). Examination of uterine tissue harvested from dams $6 \mathrm{~h}$ post-treatment confirmed the inhibition of IKK $\beta$ activity, as well as reduced the levels of p65 phosphorylation and PTGS2.

\section{Application of anti-inflammatory PGs for neuroprotection}

Together with the direct adverse effects of prematurity on the neonate, inflammation also increases the risk of neonatal brain injury. There is mounting evidence that $15 \mathrm{~d}-\mathrm{PG} \mathrm{J}_{2}$ and other anti-inflammatory cyclopentenone PGs have neuroprotective effects. In our murine model of inflammation-induced preterm labour, $15 \mathrm{~d}-\mathrm{PGJ}_{2}$ increased pup survival in LPS-treated mice from 30 to 95\% (Pirianov et al. 2009). This was associated with the inhibition of IKK $\beta$ and NFKB activity in the foetal brain. As LPS treatment leads to increased cytokine production by the foetal brain (Bell et al. 2004, Elovitz et al. 2006), inhibition of $\mathrm{NF} \kappa \mathrm{B}$ should conceptually repress cytokine production within the brain thus providing neuroprotection to the neonate.

Several animal studies have reported a neuroprotective role for $15 \mathrm{~d}-\mathrm{PGJ}_{2}$ in the presence of inflammation. Petrova et al. (1999) demonstrated in rats that $15 \mathrm{~d}-\mathrm{PGJ}_{2}$ reduces $\mathrm{NF \kappa B}$ activity in LPSstimulated microglia and IL1 $\beta$-stimulated astrocytes. Moreover, $15 \mathrm{~d}-\mathrm{PG} \mathrm{J}_{2}$ also provides significant neuroprotection in a rodent model of ischaemic white matter injury, which is associated with an inhibition of p65 nuclear translocation, TNF $\alpha$ and IL1 $\beta$ production (Nicholson et al. 2012).

Despite much research indicating beneficial effects of anti-inflammatory cyclopentenone PGs in in vitro and in vivo animal models of preterm birth, clinical studies have yet to be undertaken. There is a problem relating to the general instability of these compounds and their insolubility in water; however, studies are underway investigating liposome suspension formulations (Fukushima et al. 2000). In addition, clinical studies of new drugs in pregnancy, particularly in the context of preterm labour, have been historically challenging. Although concentrations used in vitro are higher, it must not be forgotten that these are endogenous compounds, and that $15 \mathrm{~d}-\mathrm{PG} \mathrm{J}_{2}$ is detectable in amniotic fluid (Helliwell et al. 2006) and placenta (Jawerbaum et al. 2004). Therefore, it is not beyond possibility that these anti-inflammatory PGs may soon reach the clinical setting.

\section{Conclusion}

Targeting NFאB with cyclopentenone PGs is a potential therapeutic strategy for the prevention of inflammationinduced preterm labour. $15 \mathrm{~d}-\mathrm{PGJ}_{2}$ holds the most promise because it has higher potency due to the presence of two electrophilic carbons in its chemical structure. There is now abundant evidence supporting both is anti-inflammatory effects and its potential inhibitory effects on labour-associated genes. It therefore follows that in addition to it potentially delaying inflammation-induced preterm labour, it may also serve as a neuroprotective treatment for the unborn foetus.

\section{Declaration of interest}

The authors declare that there is no conflict of interest that could be perceived as prejudicing the impartiality of the review.

\section{Funding}

This review did not receive any specific grant from any funding agency in the public, commercial or not-for-profit sector.

\section{Acknowledgements}

Prof. P R Bennett, Mr T G Teoh, Drs L Sykes and D A Maclntyre are supported by Imperial College Healthcare and the NIHR Biomedical Research Centre. The opinions are of the authors and not necessarily the opinions of Imperial College Healthcare or the NHS.

\section{References}

Ackerman WE IV, Zhang XL, Rovin BH \& Kniss DA 2005 Modulation of cytokine-induced cyclooxygenase 2 expression by PPARG ligands through NFKB signal disruption in human WISH and amnion cells. Biology of Reproduction 73 527-535. (doi:10.1095/biolreprod.104. 039032)

Allport VC, Pieber D, Slater DM, Newton R, White JO \& Bennett PR 2001 Human labour is associated with nuclear factor- $\kappa \mathrm{B}$ activity which mediates cyclo-oxygenase-2 expression and is involved with the 'functional progesterone withdrawal'. Molecular Human Reproduction 7 581-586. (doi:10.1093/molehr/7.6.581)

Aoki T \& Narumiya S 2012 Prostaglandins and chronic inflammation. Trends in Pharmacological Sciences 33 304-311. (doi:10.1016/j.tips. 2012.02.004)

Arulkumaran S, Kandola MK, Hoffman B, Hanyaloglu AC, Johnson MR \& Bennett PR 2012 The roles of prostaglandin EP 1 and 3 receptors in the control of human myometrial contractility. Journal of Clinical Endocrinology and Metabolism 97 489-498. (doi:10.1210/jc.2011-1991)

Astle S, Newton R, Thornton S, Vatish M \& Slater DM 2007 Expression and regulation of prostaglandin $\mathrm{E}$ synthase isoforms in human myometrium with labour. Molecular Human Reproduction 13 69-75. (doi:10.1093/ molehr/gal093)

Becher N, Adams Waldorf K, Hein M \& Uldbjerg N 2009 The cervical mucus plug: structured review of the literature. Acta Obstetricia et Gynecologica Scandinavica 88 502-513. (doi:10.1080/0001634090 2852898) 
Bell MJ, Hallenbeck JM \& Gallo V 2004 Determining the fetal inflammatory response in an experimental model of intrauterine inflammation in rats. Pediatric Research 56 541-546. (doi:10.1203/01.PDR.0000139407. 89883.6B)

Belt AR, Baldassare II, Molnar M, Romero R \& Hertelendy F 1999 The nuclear transcription factor NF- $\mathrm{KB}$ mediates interleukin-1 $\beta$-induced expression of cyclooxygenase-2 in human myometrial cells. American Journal of Obstetrics and Gynecology 181 359-366. (doi:10.1016/ S0002-9378(99)70562-4)

Bennett P, Slater D, Berger L \& Moor G 1994 The expression of phospholipase A2 and lipocortins (annexins) I, II and V in human fetal membranes and placenta in association with labour. Prostaglandins $\mathbf{4 8}$ 81-90. (doi:10.1016/0090-6980(94)90086-8)

Berghella V, Keeler SM, To MS, Althuisius SM \& Rust OA 2010 Effectiveness of cerclage according to severity of cervical length shortening: a metaanalysis. Ultrasound in Obstetrics \& Gynecology 35 468-473. (doi:10. 1002/uog.7547)

Berghella V, Rafael TJ, Szychowski JM, Rust OA \& Owen J 2011 Cerclage for short cervix on ultrasonography in women with singleton gestations and previous preterm birth: a meta-analysis. Obstetrics and Gynecology 117 663-671. (doi:10.1097/AOG.0b013e31820ca847)

Berry EB, Keelan JA, Helliwell RJ, Gilmour RS \& Mitchell MD 2005 Nanomolar and micromolar effects of 15-deoxy- $\Delta$ 12,14-prostaglandin J2 on amnion-derived WISH epithelial cells: differential roles of peroxisome proliferator-activated receptors $\gamma$ and $\delta$ and nuclear factor кB. Molecular Pharmacology 68 169-178. (doi:10.1124/mol.104. 009449)

Bisits AM, Smith R, Mesiano S, Yeo G, Kwek K, MacIntyre D \& Chan EC 2005 Inflammatory aetiology of human myometrial activation tested using directed graphs. PLoS Computational Biology 1 132-136. (doi:10. 1371/journal.pcbi.0010019)

Blank V, Hirsch E, Challis JR, Romero R \& Lye SJ 2008 Cytokine signaling, inflammation, innate immunity and preterm labour - a workshop report. Placenta 29 (Suppl A) S102-S104. (doi:10.1016/j.placenta.2007.10.011)

Blanks AM, Shmygol A \& Thornton S 2007 Preterm labour. Myometrial function in prematurity. Best Practice \& Research. Clinical Obstetrics \& Gynaecology 21 807-819. (doi:10.1016/j.bpobgyn.2007.03.003)

Blencowe H, Cousens S, Oestergaard MZ, Chou D, Moller AB, Narwal R, Adler A, Vera Garcia C, Rohde S, Say L et al. 2012 National, regional, and worldwide estimates of preterm birth rates in the year 2010 with time trends since 1990 for selected countries: a systematic analysis and implications. Lancet 379 2162-2172. (doi:10.1016/S0140-6736(12) 60820-4)

Casey ML \& MacDonald PC 1988 Biomolecular processes in the initiation of parturition: decidual activation. Clinical Obstetrics and Gynecology 31 533-552. (doi:10.1097/00003081-198809000-00005)

Cernuda-Morollon E, Pineda-Molina E, Canada FJ \& Perez-Sala D 2001 15-Deoxy- $\Delta$ 12,14-prostaglandin J2 inhibition of NF-KB-DNA binding through covalent modification of the p50 subunit. Journal of Biological Chemistry 276 35530-35536. (doi:10.1074/jbc.M104518200)

Chen Z, Hagler J, Palombella VJ, Melandri F, Scherer D, Ballard D \& Maniatis T 1995 Signal-induced site-specific phosphorylation targets I $\mathrm{B} \alpha$ to the ubiquitin-proteasome pathway. Genes and Development 9 1586-1597. (doi:10.1101/gad.9.13.1586)

Choi SJ, Oh S, Kim JH \& Roh CR 2007 Changes of nuclear factor $\kappa B$ (NF-KB), cyclooxygenase-2 (COX-2) and matrix metalloproteinase-9 (MMP-9) in human myometrium before and during term labor. European Journal of Obstetrics, Gynecology, and Reproductive Biology 132 182-188. (doi:10.1016/j.ejogrb.2006.07.024)

Christiaens I, Zaragoza DB, Guilbert L, Robertson SA, Mitchell BF \& Olson DM 2008 Inflammatory processes in preterm and term parturition. Journal of Reproductive Immunology 79 50-57. (doi:10.1016/j.jri.2008. 04.002)

Condon JC, Jeyasuria P, Faust JM \& Mendelson CR 2004 Surfactant protein secreted by the maturing mouse fetal lung acts as a hormone that signals the initiation of parturition. PNAS 101 4978-4983. (doi:10.1073/pnas. 0401124101)

Crankshaw DJ \& Dyal R 1994 Effects of some naturally occurring prostanoids and some cyclooxygenase inhibitors on the contractility of the human lower uterine segment in vitro. Canadian Journal of Physiology and Pharmacology 72 870-874. (doi:10.1139/y94-123)
Curry AE, Vogel I, Drews C, Schendel D, Skogstrand K, Flanders WD, Hougaard D, Olsen J \& Thorsen P 2007 Mid-pregnancy maternal plasma levels of interleukin 2, 6, and 12, tumor necrosis factor- $\alpha$, interferon- $\gamma$, and granulocyte-macrophage colony-stimulating factor and spontaneous preterm delivery. Acta Obstetricia et Gynecologica Scandinavica 86 1103-1110. (doi:10.1080/00016340701515423)

Diez-Dacal B \& Perez-Sala D 2012 A-class prostaglandins: early findings and new perspectives for overcoming tumor chemoresistance. Cancer Letters 320 150-157. (doi:10.1016/j.canlet.2012.03.003)

Duggan PJ, Maalouf EF, Watts TL, Sullivan MH, Counsell SJ, Allsop J, Al-Nakib L, Rutherford MA, Battin M, Roberts I et al. 2001 Intrauterine T-cell activation and increased proinflammatory cytokine concentrations in preterm infants with cerebral lesions. Lancet 358 1699-1700. (doi:10.1016/S0140-6736(01)06723-X)

Ekman G, Malmstrom A, Uldbjerg N \& Ulmsten U 1986 Cervical collagen: an important regulator of cervical function in term labor. Obstetrics and Gynecology 67 633-636. (doi:10.1097/00006250-198605000-00006)

Elliott CL, Allport VC, Loudon JA, Wu GD \& Bennett PR 2001 Nuclear factor- $\mathrm{KB}$ is essential for up-regulation of interleukin-8 expression in human amnion and cervical epithelial cells. Molecular Human Reproduction 7 787-790. (doi:10.1093/molehr/7.8.787)

Elovitz MA, Mrinalini C \& Sammel MD 2006 Elucidating the early signal transduction pathways leading to fetal brain injury in preterm birth. Pediatric Research 59 50-55. (doi:10.1203/01.pdr.0000191141. 21932.b6)

Fanaroff AA, Hack M \& Walsh MC 2003 The NICHD neonatal research network: changes in practice and outcomes during the first 15 years. Seminars in Perinatology 27 281-287. (doi:10.1016/S0146-0005(03) 00055-7)

da Fonseca EB, Bittar RE, Carvalho MH \& Zugaib M 2003 Prophylactic administration of progesterone by vaginal suppository to reduce the incidence of spontaneous preterm birth in women at increased risk: a randomized placebo-controlled double-blind study. American Journal of Obstetrics and Gynecology 188 419-424. (doi:10.1067/mob.2003.41)

Fonseca EB, Celik E, Parra M, Singh M, Nicolaides KH \& Fetal Medicine Foundation Second Trimester Screening Group 2007 Progesterone and the risk of preterm birth among women with a short cervix. New England Journal of Medicine 357 462-469. (doi:10.1056/NEJMoa067815)

Friebe-Hoffmann U, Chiao JP \& Rauk PN 2001 Effect of IL-1 $\beta$ and IL-6 on oxytocin secretion in human uterine smooth muscle cells. American Journal of Reproductive Immunology 46 226-231. (doi:10.1034/j.16000897.2001.d01-6.x)

Fukushima S, Kishimoto S, Takeuchi Y \& Fukushima M 2000 Preparation and evaluation of o/w type emulsions containing antitumor prostaglandin. Advanced Drug Delivery Reviews 45 65-75. (doi:10.1016/S0169409X(00)00101-0)

Funk CD 2001 Prostaglandins and leukotrienes: advances in eicosanoid biology. Science 294 1871-1875. (doi:10.1126/science.294.5548.1871)

Gharbi S, Garzon B, Gayarre J, Timms J \& Perez-Sala D 2007 Study of protein targets for covalent modification by the antitumoral and antiinflammatory prostaglandin PGA1: focus on vimentin. Journal of Mass Spectrometry 42 1474-1484. (doi:10.1002/jms.1291)

Giannoulias D, Patel FA, Holloway AC, Lye SJ, Tai HH \& Challis JR 2002 Differential changes in 15-hydroxyprostaglandin dehydrogenase and prostaglandin $\mathrm{H}$ synthase (types $\mathrm{I}$ and II) in human pregnant myometrium. Journal of Clinical Endocrinology and Metabolism 87 1345-1352. (doi:10.1210/jcem.87.3.8317)

Goldenberg RL, Hauth JC \& Andrews WW 2000 Intrauterine infection and preterm delivery. New England Journal of Medicine 342 1500-1507. (doi:10.1056/NEJM200005183422007)

Goldenberg RL, Gravett MG, lams J, Papageorghiou AT, Waller SA, Kramer M, Culhane J, Barros F, Conde-Agudelo A, Bhutta ZA et al. 2012 The preterm birth syndrome: issues to consider in creating a classification system. American Journal of Obstetrics and Gynecology 206 113-118. (doi:10.1016/j.ajog.2011.10.865)

Gomez R, Romero R, Nien JK, Chaiworapongsa T, Medina L, Kim YM, Yoon BH, Carstens M, Espinoza J, lams JD \& Gonzalez R 2005a A short cervix in women with preterm labor and intact membranes: a risk factor for microbial invasion of the amniotic cavity. American Journal of Obstetrics and Gynecology 192 678-689. (doi:10.1016/j.ajog.2004. 10.624) 
Gomez PF, Pillinger MH, Attur M, Marjanovic N, Dave M, Park J, Bingham CO III, Al-Mussawir H \& Abramson SB 2005b Resolution of inflammation: prostaglandin E2 dissociates nuclear trafficking of individual NF-kB subunits (p65, p50) in stimulated rheumatoid synovial fibroblasts. Journal of Immunology 175 6924-6930. (doi:10.4049/ jimmunol.175.10.6924)

Gravett MG, Rubens CE, Nunes TM \& Group GR 2010 Global report on preterm birth and stillbirth (2 of 7): discovery science. BMC Pregnancy and Childbirth 10 (Suppl 1) S2. (doi:10.1186/1471-2393-10-S1-S2)

Hassan S, Romero R, Hendler I, Gomez R, Khalek N, Espinoza J, Nien JK, Berry SM, Bujold E, Camacho N et al. 2006 A sonographic short cervix as the only clinical manifestation of intra-amniotic infection. Journal of Perinatal Medicine 34 13-19. (doi:10.1515/JPM.2006.002)

Hassan SS, Romero R, Vidyadhari D, Fusey S, Baxter JK, Khandelwal M, Vijayaraghavan J, Trivedi Y, Soma-Pillay P, Sambarey P et al. 2011 Vaginal progesterone reduces the rate of preterm birth in women with a sonographic short cervix: a multicenter, randomized, double-blind, placebo-controlled trial. Ultrasound in Obstetrics \& Gynecology 38 18-31. (doi:10.1002/uog.9017)

Helliwell RJ, Keelan JA, Marvin KW, Adams L, Chang MC, Anand A, Sato TA, O'Carroll S, Chaiworapongsa T, Romero RJ et al. 2006 Gestational age-dependent up-regulation of prostaglandin D synthase (PGDS) and production of PGDS-derived antiinflammatory prostaglandins in human placenta. Journal of Clinical Endocrinology and Metabolism 91 597-606. (doi:10.1210/jc.2005-1982)

Hertelendy F \& Zakar T 2004 Prostaglandins and the myometrium and cervix. Prostaglandins, Leukotriens, and Essential Fatty Acids $\mathbf{7 0}$ 207-222. (doi:10.1016/j.plefa.2003.04.009)

Hilkens CM, Snijders A, Snijdewint FG, Wierenga EA \& Kapsenberg ML 1996 Modulation of T-cell cytokine secretion by accessory cell-derived products. European Respiratory Journal. Supplement (22) 90s-94s. (doi:10.1186/1742-4755-10-S1-S2)

Howson CP, Kinney MV \& Lawn JE 2012 Born too soon: the global action report on preterm birth. World Health Organization.

Hunt JS 1989 Cytokine networks in the uteroplacental unit: macrophages as pivotal regulatory cells. Journal of Reproductive Immunology 16 1-17. (doi:10.1016/0165-0378(89)90002-8)

Jawerbaum A, Capobianco E, Pustovrh C, White V, Baier M, Salzberg S, Pesaresi M \& Gonzalez E 2004 Influence of peroxisome proliferatoractivated receptor $\gamma$ activation by its endogenous ligand 15-deoxy $\Delta 12,14$ prostaglandin $\mathrm{J} 2$ on nitric oxide production in term placental tissues from diabetic women. Molecular Human Reproduction 10 671-676. (doi:10.1093/molehr/gah090)

Karin M \& Ben-Neriah Y 2000 Phosphorylation meets ubiquitination: the control of NF-[к]B activity. Annual Review of Immunology 18 621-663. (doi:10.1146/annurev.immunol.18.1.621)

Keelan JA, Blumenstein M, Helliwell RJ, Sato TA, Marvin KW \& Mitchell MD 2003 Cytokines, prostaglandins and parturition - a review. Placenta 24 (Suppl A) S33-S46. (doi:10.1053/plac.2002.0948)

Khanjani S, Kandola MK, Lindstrom TM, Sooranna SR, Melchionda M, Lee YS, Terzidou V, Johnson MR \& Bennett PR 2011 NF- $\kappa$ B regulates a cassette of immune/inflammatory genes in human pregnant myometrium at term. Journal of Cellular and Molecular Medicine 15 809-824. (doi:10.1111/j.1582-4934.2010.01069.x)

Lappas M \& Rice GE 2007 The role and regulation of the nuclear factor KB signalling pathway in human labour. Placenta 28 543-556. (doi:10. 1016/j.placenta.2006.05.011)

Lappas M \& Rice GE 2009 Transcriptional regulation of the processes of human labour and delivery. Placenta 30 S90-S95. (doi:10.1016/ j.placenta.2008.10.005)

Lappas M, Permezel M, Georgiou HM \& Rice GE 2002 Regulation of proinflammatory cytokines in human gestational tissues by peroxisome proliferator-activated receptor- $\gamma$ : effect of 15 -deoxy- $\Delta(12,14)-P G J(2)$ and troglitazone. Journal of Clinical Endocrinology and Metabolism 87 4667-4672. (doi:10.1210/jc.2002-020613)

Liang Z, Sooranna SR, Engineer N, Tattersall M, Khanjani S, Bennett PR, Myatt L \& Johnson MR 2008 Prostaglandin F2- $\alpha$ receptor regulation in human uterine myocytes. Molecular Human Reproduction 14 215-223. (doi:10.1093/molehr/gan008)

Lim S, MacIntyre DA, Lee YS, Khanjani S, Terzidou V, Teoh TG \& Bennett PR 2012 Nuclear factor $\mathrm{KB}$ activation occurs in the amnion prior to labour onset and modulates the expression of numerous labour associated genes. PLOS ONE 7 e34707. (doi:10.1371/journal.pone. 0034707)

Lindstrom TM \& Bennett PR 2005a The role of nuclear factor $\kappa B$ in human labour. Reproduction 130 569-581. (doi:10.1530/rep.1.00197)

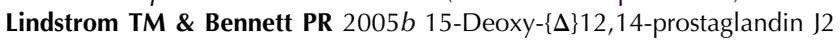

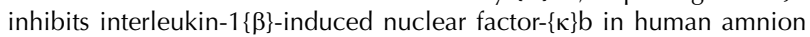
and myometrial cells: mechanisms and implications. Journal of Clinical Endocrinology and Metabolism 90 3534-3543. (doi:10.1210/jc.20050055)

Liu L, Johnson HL, Cousens S, Perin J, Scott S, Lawn JE, Rudan I, Campbell H, Cibulskis R, Li M et al. 2012 Global, regional, and national causes of child mortality: an updated systematic analysis for 2010 with time trends since 2000. Lancet 379 2151-2161. (doi:10.1016/ S0140-6736(12)60560-1)

Makhseed M, Raghupathy R, El-Shazly S, Azizieh F, Al-Harmi JA \& Al-Azemi MM 2003 Pro-inflammatory maternal cytokine profile in preterm delivery. American Journal of Reproductive Immunology $\mathbf{4 9}$ 308-318. (doi:10.1034/j.1600-0897.2003.00038.x)

Mandal AK, Zhang Z, Kim SJ, Tsai PC \& Mukherjee AB 2005 Yin-yang: balancing act of prostaglandins with opposing functions to regulate inflammation. Journal of Immunology 175 6271-6273. (doi:10.4049/ jimmunol.175.10.6271)

McCracken SA, Drury CL, Lee HS \& Morris JM 2003 Pregnancy is associated with suppression of the nuclear factor $\kappa \mathrm{B} / \mathrm{l} \kappa \mathrm{B}$ activation pathway in peripheral blood mononuclear cells. Journal of Reproductive Immunology 58 27-47. (doi:10.1016/S0165-0378(02)00081-5)

McCracken SA, Gallery E \& Morris JM 2004 Pregnancy-specific downregulation of NF-KB expression in T cells in humans is essential for the maintenance of the cytokine profile required for pregnancy success. Journal of Immunology 172 4583-4591. (doi:10.4049/jimmunol.172. 7.4583)

McCracken SA, Hadfield K, Rahimi Z, Gallery ED \& Morris JM 2007 NF-kB-regulated suppression of T-bet in T cells represses Th1 immune responses in pregnancy. European Journal of Immunology 37 1386-1396. (doi:10.1002/eji.200636322)

McLaren J, Taylor DJ \& Bell SC 2000 Prostaglandin E(2)-dependent production of latent matrix metalloproteinase-9 in cultures of human fetal membranes. Molecular Human Reproduction 6 1033-1040. (doi:10.1093/molehr/6.11.1033)

Meis PJ, Klebanoff M, Thom E, Dombrowski MP, Sibai B, Moawad AH, Spong CY, Hauth JC, Miodovnik M, Varner MW et al. 2003 Prevention of recurrent preterm delivery by $17 \alpha$-hydroxyprogesterone caproate. New England Journal of Medicine 348 2379-2385. (doi:10.1056/ NEJMoa035140)

Menon R \& Fortunato SJ 2004 Fetal membrane inflammatory cytokines: a switching mechanism between the preterm premature rupture of the membranes and preterm labor pathways. Journal of Perinatal Medicine 32 391-399. (doi:10.1515/JPM.2004.134)

Mitchell MD, Edwin S \& Romero RJ 1990 Prostaglandin biosynthesis by human decidual cells: effects of inflammatory mediators. Prostaglandins, Leukotriens, and Essential Fatty Acids 41 35-38. (doi:10.1016/09523278(90)90128-8)

Molnar M, Romero R \& Hertelendy F 1993 Interleukin-1 and tumor necrosis factor stimulate arachidonic acid release and phospholipid metabolism in human myometrial cells. American Journal of Obstetrics and Gynecology 169 825-829. (doi:10.1016/0002-9378(93) 90011-7)

Morita I 2002 Distinct functions of COX-1 and COX-2. Prostaglandins \& Other Lipid Mediators 68-69 165-175. (doi:10.1016/S0090-6980 (02)00029-1)

Napimoga MH, Vieira SM, Dal-Secco D, Freitas A, Souto FO, Mestriner FL, Alves-Filho JC, Grespan R, Kawai T, Ferreira SH et al. 2008 Peroxisome proliferator-activated receptor- $\gamma$ ligand, 15-deoxy- $\Delta 12,14-$ prostaglandin J2, reduces neutrophil migration via a nitric oxide pathway. Journal of Immunology 180 609-617. (doi:10.4049/jimmunol.180.1.609)

Narumiya S \& Fukushima M 1987 Active transport and cellular accumulation of cyclopentenone prostaglandins: a mechanism of prostaglandin-induced growth inhibition. Advances in Prostaglandin and Thromboxane Research 17B 972-975. 
Nath CA, Ananth CV, Smulian JC \& Peltier MR 2010 Can sulfasalazine prevent infection-mediated pre-term birth in a murine model? American Journal of Reproductive Immunology 63 144-149. (doi:10.1111/j.16000897.2009.00773.x)

Nicholson JD, Puche AC, Guo Y, Weinreich D, Slater BJ \& Bernstein SL 2012 PGJ(2) provides prolonged CNS stroke protection by reducing white matter edema. PLOS ONE 7 e50021. (doi:10.1371/journal.pone. 0050021)

Norman M, Ekman G \& Malmstrom A 1993 Prostaglandin E2-induced ripening of the human cervix involves changes in proteoglycan metabolism. Obstetrics and Gynecology 82 1013-1020.

Norman JE, Morris C \& Chalmers J 2009 The effect of changing patterns of obstetric care in Scotland (1980-2004) on rates of preterm birth and its neonatal consequences: perinatal database study. PLoS Medicine 6 e1000153. (doi:10.1371/journal.pmed.1000153)

Ogawa M, Hirano H, Tsubaki H, Kodama H \& Tanaka T 1998 The role of cytokines in cervical ripening: correlations between the concentrations of cytokines and hyaluronic acid in cervical mucus and the induction of hyaluronic acid production by inflammatory cytokines by human cervical fibroblasts. American Journal of Obstetrics and Gynecology 179 105-110. (doi:10.1016/S0002-9378(98)70258-3)

Olson DM \& Ammann C 2007 Role of the prostaglandins in labour and prostaglandin receptor inhibitors in the prevention of preterm labour. Frontiers in Bioscience 12 1329-1343. (doi:10.2741/2151)

Olson DM, Opavsky MA \& Challis JR 1983 Prostaglandin synthesis by human amnion is dependent upon extracellular calcium. Canadian Journal of Physiology and Pharmacology 61 1089-1092. (doi:10.1139/ y83-163)

Parkington HC, Tonta MA, Davies NK, Brennecke SP \& Coleman HA 1999 Hyperpolarization and slowing of the rate of contraction in human uterus in pregnancy by prostaglandins E2 and f2 $\alpha$ : involvement of the $\mathrm{Na}^{+}$ pump. Journal of Physiology 514 229-243. (doi:10.1111/j.1469-7793. 1999.229af.x)

Perez-Sala D, Cernuda-Morollon E \& Canada FJ 2003 Molecular basis for the direct inhibition of AP-1 DNA binding by 15 -deoxy- $\Delta 12,14$ prostaglandin J2. Journal of Biological Chemistry 278 51251-51260. (doi:10.1074/jbc.M309409200)

Petrova TV, Akama KT \& Van Eldik LJ 1999 Cyclopentenone prostaglandins suppress activation of microglia: down-regulation of inducible nitricoxide synthase by 15-deoxy- $\Delta 12,14$-prostaglandin J2. PNAS 96 4668-4673. (doi:10.1073/pnas.96.8.4668)

Pirianov G, Waddington SN, Lindstrom TM, Terzidou V, Mehmet H \& Bennett PR 2009 The cyclopentenone 15-deoxy- $\mathbf{1 2 , 1 4 - p r o s t a g l a n d i n}$ $J(2)$ delays lipopolysaccharide-induced preterm delivery and reduces mortality in the newborn mouse. Endocrinology 150 699-706. (doi:10. 1210/en.2008-1178)

Pollard JK \& Mitchell MD 1996a Effects of gestational age on prostaglandin production and its regulation in human myometrial cells. Journal of Maternal-Fetal Medicine 5 93-98. (doi:10.1002/(SICI)1520-6661 (199603/04)5:2 < 93::AID-MFM9>3.0.CO;2-L)

Pollard JK \& Mitchell MD $1996 b$ Intrauterine infection and the effects of inflammatory mediators on prostaglandin production by myometrial cells from pregnant women. American Journal of Obstetrics and Gynecology 174 682-686. (doi:10.1016/S0002-9378(96)70450-7)

Raghupathy R, Makhseed M, El-Shazly S, Azizieh F, Farhat R \& Ashkanani L 2001 Cytokine patterns in maternal blood after premature rupture of membranes. Obstetrics and Gynecology 98 122-126. (doi:10.1016/ S0029-7844(01)01408-9)

Ramirez MM, Fraher LJ, Goltzman D, Hendy GN, Matthews SG, Sangha R \& Challis JR 1995 Immunoreactive parathyroid hormone-related protein: its association with preterm labor. European Journal of Obstetrics, Gynecology, and Reproductive Biology 63 21-26. (doi:10.1016/03012115(95)98586-S)

Ricciotti E \& FitzGerald GA 2011 Prostaglandins and inflammation. Arteriosclerosis, Thrombosis, and Vascular Biology 31 986-1000. (doi:10.1161/ATVBAHA.110.207449)

Rice GE, Brennecke SP, Scott KF, Smith GM, Rajkovic IA \& Bishop GJ 1992 Elevated maternal plasma immunoreactive phospholipase A2 in human preterm and term labour. Eicosanoids 5 9-12.

Ricote M, Li AC, Willson TM, Kelly CJ \& Glass CK 1998 The peroxisome proliferator-activated receptor- $\gamma$ is a negative regulator of macrophage activation. Nature 391 79-82. (doi:10.1038/34178)
Romero R \& Mazor M 1988 Infection and preterm labor. Clinical Obstetrics and Gynecology 31 553-584. (doi:10.1097/00003081-19880900000006)

Romero R, Durum S, Dinarello CA, Oyarzun e, Hobbins JC \& Mitchell MD 1989 Interleukin-1 stimulates prostaglandin biosynthesis by human amnion. Prostaglandins 37 13-22. (doi:10.1016/00906980(89)90028-2)

Saito S, Tsuda H \& Michimata T 2002 Prostaglandin D2 and reproduction. American Journal of Reproductive Immunology 47 295-302. (doi:10. 1034/j.1600-0897.2002.01113.x)

Sangha RK, Walton JC, Ensor CM, Tai HH \& Challis JR 1994 Immunohistochemical localization, messenger ribonucleic acid abundance, and activity of 15-hydroxyprostaglandin dehydrogenase in placenta and fetal membranes during term and preterm labor. Journal of Clinical Endocrinology and Metabolism 78 982-989. (doi:10.1210/jcem.78.4.8157731)

Santoro MG, Fukushima M, Benedetto A \& Amici C 1987 PGJ2, a new antiviral prostaglandin: inhibition of Sendai virus replication and alteration of virus protein synthesis. Journal of General Virology 68 1153-1158. (doi:10.1099/0022-1317-68-4-1153)

Scher JU \& Pillinger MH 2009 The anti-inflammatory effects of prostaglandins. Journal of Investigative Medicine 57 703-708. (doi:10. 231/JIM.0b013e31819aaa76)

Schonbeck U, Mach F \& Libby P 1998 Generation of biologically active IL-1 $\beta$ by matrix metalloproteinases: a novel caspase- 1 -independent pathway of IL-1 $\beta$ processing. Journal of Immunology 161 3340-3346.

Shim SS, Romero R, Hong JS, Park CW, Jun JK, Kim BI \& Yoon BH 2004 Clinical significance of intra-amniotic inflammation in patients with preterm premature rupture of membranes. American Journal of Obstetrics and Gynecology 191 1339-1345. (doi:10.1016/j.ajog.2004. 06.085)

Simmons DL, Botting RM \& Hla T 2004 Cyclooxygenase isozymes: the biology of prostaglandin synthesis and inhibition. Pharmacological Reviews 56 387-437. (doi:10.1124/pr.56.3.3)

Slater D, Dennes W, Sawdy R, Allport V \& Bennett P 1999a Expression of cyclo-oxygenase types- 1 and -2 in human fetal membranes throughout pregnancy. Journal of Molecular Endocrinology 22 125-130. (doi:10. 1677/jme.0.0220125)

Slater DM, Dennes WJ, Campa JS, Poston L \& Bennett PR $1999 \mathrm{~b}$ Expression of cyclo-oxygenase types-1 and -2 in human myometrium throughout pregnancy. Molecular Human Reproduction 5 880-884. (doi:10.1093/ molehr/5.9.880)

Slater DM, Astle S, Bennett PR \& Thornton S 2004 Labour is associated with increased expression of type-IIA secretory phospholipase A2 but not type-IV cytosolic phospholipase A2 in human myometrium. Molecular Human Reproduction 10 799-805. (doi:10.1093/molehr/gah103)

Slater DM, Astle S, Woodcock N, Chivers JE, de Wit NC, Thornton S, Vatish M \& Newton R 2006 Anti-inflammatory and relaxatory effects of prostaglandin E2 in myometrial smooth muscle. Molecular Human Reproduction 12 89-97. (doi:10.1093/molehr/gal005)

Soloff MS, Cook DL Jr, Jeng YJ \& Anderson GD 2004 In situ analysis of interleukin-1-induced transcription of cox-2 and il-8 in cultured human myometrial cells. Endocrinology 145 1248-1254. (doi:10.1210/ en.2003-1310)

Storer PD, Xu J, Chavis JA \& Drew PD 2005 Cyclopentenone prostaglandins PGA2 and 15-deoxy- $\Delta 12,14$ PG)2 suppress activation of murine microglia and astrocytes: implications for multiple sclerosis. Journal of Neuroscience Research 80 66-74. (doi:10.1002/jnr.20413)

Straus DS \& Glass CK 2001 Cyclopentenone prostaglandins: new insights on biological activities and cellular targets. Medicinal Research Reviews 21 185-210. (doi:10.1002/med.1006)

Sykes L, Macintyre DA, Teoh TG \& Bennett PR 2011 Targeting immune activation in the prevention of preterm labour. European Obstetrics \& Gynaecology 6 100-106.

Sykes L, MacIntyre DA, Yap XJ, Teoh TG \& Bennett PR 2012a The Th1:th2 dichotomy of pregnancy and preterm labour. Mediators of Inflammation 2012 967629. (doi:10.1155/2012/967629)

Sykes L, Lee Y, Khanjani S, Macintyre DA, Yap XJ, Ponnampalam S, Teoh TG \& Bennett PR 2012b Chemoattractant receptor homologous to the T helper 2 cell (CRTH2) is not expressed in human amniocytes and myocytes. PLOS ONE 7 e50734. (doi:10.1371/journal.pone. 0050734) 
Sykes L, Macintyre DA, Yap XJ, Ponnampalam S, Teoh TG \& Bennett PR $2012 c$ Changes in the Th1:Th2 cytokine bias in pregnancy and the effects of the anti-inflammatory cyclopentenone prostaglandin 15-deoxy$\Delta(12,14)$-prostaglandin J2. Mediators of Inflammation 2012416739.

Tattersall M, Engineer N, Khanjani S, Sooranna SR, Roberts VH, Grigsby PL, Liang Z, Myatt L \& Johnson MR 2008 Pro-labour myometrial gene expression: are preterm labour and term labour the same? Reproduction 135 569-579. (doi:10.1530/REP-07-0461)

Terzidou V, Lee Y, Lindstrom T, Johnson M, Thornton S \& Bennett PR 2006 Regulation of the human oxytocin receptor by nuclear factor- $\kappa \mathrm{B}$ and CCAAT/enhancer-binding protein- $\beta$. Journal of Clinical Endocrinology and Metabolism 91 2317-2326. (doi:10.1210/jc.2005-2649)

Thomson AJ, Telfer JF, Young A, Campbell S, Stewart CJ, Cameron IT, Greer IA \& Norman JE 1999 Leukocytes infiltrate the myometrium during human parturition: further evidence that labour is an inflammatory process. Human Reproduction 14 229-236. (doi:10.1093/ humrep/14.1.229)

Todd HM, Dundoo VL, Gerber WR, Cwiak CA, Baldassare JJ \& Hertelendy F 1996 Effect of cytokines on prostaglandin E2 and prostacyclin production in primary cultures of human myometrial cells. Journal of Maternal-Fetal Medicine 5 161-167. (doi:10.1002/ (SICl)1520-6661(199607/08)5:4<161::AID-MFM1 > 3.0.CO;2-I)

Ulug U, Goldman S, Ben-Shlomo I \& Shalev E 2001 Matrix metalloproteinase (MMP)-2 and MMP-9 and their inhibitor, TIMP-1, in human term decidua and fetal membranes: the effect of prostaglandin $F(2 \alpha)$ and indomethacin. Molecular Human Reproduction 7 1187-1193. (doi:10. 1093/molehr/7.12.1187)

Villar J, Papageorghiou AT, Knight HE, Gravett MG, lams J, Waller SA, Kramer M, Culhane JF, Barros FC, Conde-Agudelo A et al. 2012 The preterm birth syndrome: a prototype phenotypic classification. American Journal of Obstetrics and Gynecology 206 119-123. (doi:10.1016/j.ajog. 2011.10.866)

Wright HL, Moots RJ, Bucknall RC \& Edwards SW 2010 Neutrophil function in inflammation and inflammatory diseases. Rheumatology $\mathbf{4 9}$ 1618-1631. (doi:10.1093/rheumatology/keq045)
Xu C, Long A, Fang X, Wood SL, Slater DM, Ni X \& Olson DM 2013 Effects of PGF $2 \alpha$ on the expression of uterine activation proteins in pregnant human myometrial cells from upper and lower segment. Journal of Clinical Endocrinology and Metabolism 98 2975-2983. (doi:10.1210/jc. 2012-2829)

Yoon BH, Jun JK, Romero R, Park KH, Gomez R, Choi JH \& Kim IO 1997 Amniotic fluid inflammatory cytokines (interleukin-6, interleukin-1 $\beta$, and tumor necrosis factor- $\alpha$ ), neonatal brain white matter lesions, and cerebral palsy. American Journal of Obstetrics and Gynecology 177 19-26. (doi:10.1016/S0002-9378(97)70432-0)

Yoon BH, Romero R, Kim KS, Park JS, Ki SH, Kim BI \& Jun JK 1999 A systemic fetal inflammatory response and the development of bronchopulmonary dysplasia. American Journal of Obstetrics and Gynecology 181 773-779. (doi:10.1016/S0002-9378(99)70299-1)

Yuan TM, Sun Y, Zhan CY \& Yu HM 2010 Intrauterine infection/inflammation and perinatal brain damage: role of glial cells and Toll-like receptor signaling. Journal of Neuroimmunology 229 16-25. (doi:10.1016/j. jneuroim.2010.08.008)

Zandi E, Rothwarf DM, Delhase M, Hayakawa M \& Karin M 1997 The ІкB kinase complex (IKK) contains two kinase subunits, IKK $\alpha$ and IKK $\beta$,

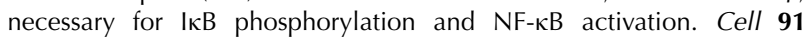
243-252. (doi:10.1016/S0092-8674(00)80406-7)

Zaragoza DB, Wilson RR, Mitchell BF \& Olson DM 2006 The interleukin $1 \beta$-induced expression of human prostaglandin F2 $\alpha$ receptor messenger RNA in human myometrial-derived ULTR cells requires the transcription factor, NFkB. Biology of Reproduction 75 697-704. (doi:10.1095/ biolreprod.106.053439)

Received 14 November 2013

First decision 12 March 2014

Revised manuscript received 2 April 2014

Accepted 14 April 2014 